\title{
Prevalence of Diabetes Mellitus and Antidiabetic Drug Utilization in the Eastern Bosnia and Herzegovina: a Pilot Study
}

\author{
Jelena D. Popržen ${ }^{1}$, Zdenko S. Tomić ${ }^{2}$, Ana D. Tomas², \\ Milica M. Paut Kusturica ${ }^{2}$, Ana J. Sabo ${ }^{2}$, Olga J. Horvat ${ }^{2}$ \\ ${ }^{1}$ Health Institution Moja apoteka, Foča, Bosnia and Herzegovina \\ ${ }^{2}$ Department of Pharmacology and Toxicology, Faculty of Medicine Novi Sad, University of \\ Novi Sad, Novi Sad, Serbia
}

\section{SUMMARY}

There are no national estimates for the prevalence of DM in Bosnia and Herzegovina $(\mathrm{BiH})$, available data is extrapolated from neighboring countries. This study aimed to determine the prevalence of DM, as well as utilization of antidiabetic drugs (ADs) and exposure rates of $D M$ patients to $A D s$ in the eastern region of the Republic of Srpska (RS), BiH. For external reference, data were compared to that from Serbia, Hungary and Norway. Data on the number of all adult patients with DM type 1 and 2 in the three municipalities in the eastern region of RS were obtained from medical records. The use of ADs in the RS, Serbia, Hungary and Norway for the year of 2013 was analysed by ATC/Defined Daily Dose methodology. The exposure of DM patients to ADs was expressed in percentage. The recorded DM prevalence in the three observed municipalities was $6.65 \%$, with high proportion of type 1 compared to type 2 DM (25.32\% to $74.68 \%$ ). The total consumption of ADs recorded in our study was similar to those in Norway, but lower than in Serbia and Hungary. The percentage of theoretical exposure of each patient to ADs was only $78,24 \%$, similar to that in Serbia $(80.6 \%)$, whereas Norway and especially Hungary had exceptionally good exposure rates $(103,8$ and $126.5 \%$ ). High proportion of type $1 \mathrm{DM}$ patients recorded in our study indicates the insufficient detection of DM, especially type 2 , whereas the low exposure rate of patients with $D M$ to $A D$ s indicates that even the registered patients with $D M$ are undertreated. There is an urgent need for interventions in prevention and treatment of $\mathrm{DM}$ in $\mathrm{BiH}$.

Keywords: Diabetes Mellitus; antidiabetic drugs; Bosnia and Herzegovina; ATC-DDD 


\section{INTRODUCTION}

Diabetes mellitus (DM) is one of the leading chronic non-communicable diseases whose prevalence continues to rise. As estimated by the International Diabetes Federation (IDF), Turkey has the highest prevalence of DM (almost 15\%) in Europe, followed by the countries emerged from the former Yugoslavia: Montenegro (10.1\%), Macedonia (10.0\%), Serbia (9.9\%) and Bosnia and Herzegovina (BiH) $(9.7 \%)$ [1]. Although the highest prevalence in Europe was recorded in countries of the Southeastern Europe, however these estimates of diabetes prevalence in these countries reported in the IDF atlas have been made by extrapolating data from similar population.

In Bosnia and Herzegovina, one of the countries of Southeastern Europe, DM was the fourth leading cause of disability-adjusted life years in 2013 [2], and a fifth leading cause of years of life lost to premature deaths in 2013 [3]. As a cause of premature mortality, DM was significantly higher than in comparable countries [4]. Bosnia and Herzegovina consists of two entities: the Republic of Srpska (RS) and the Federation of Bosnia and Herzegovina. The prevalence of DM has been used as one of the parameters in the assessment of the quality of the health care by the World Health Organization (WHO), therefore it is extremely important to publish data on prevalence as well as quality of diabetes treatment in both enities of this country.

\section{AIM}

The aim of the study was to determine the prevalence of DM on the sample of $4,41 \%$ of the population of the RS and the utilization of antidiabetic drugs. The data were compared with the consumption data in Serbia (Southeastern country of a former Yugoslavia), Hungary (central European country) and Norway (northern European country).

\section{METHODS}

We performed a cross-sectional study on population of eastern region of the RS covered by the General Practitioners (GPs). The study was carried out on the territory of three municipalities (Foca, Trebinje, Gacko) in the eastern part of the RS with a total population 54186 (according to the 2013 census), which makes the
$4.41 \%$ sample of the population of the RS [5]. This 3 out of 19 municipalities were selected in order to represent different socio-economical regions (urban/rural, higher/lower economical status, different health services available). The source population of this study consisted of all adult patients with DM (aged 20 years and older) who were registered with the participating GPs on December 31, 2013. As the proportion of the population registered with GPs in RS is high (80\%), it enabled us to provide an accurate population denominator. DM (type 1 or 2) was considered known if the diagnosis was documented in the patient's file. The prevalence was expressed as a percentage of all adult patients with DM in relation to adult inhabitants of the three observed municipalities. The survey was approved by the Ethics Committee of University of Novi Sad.

Data on consumption of insulin and oral antidiabetic drugs issued by prescription, for the year 2013 were obtained from the Health Insurance Fund of the RS. The data on the use of antidiabetic drugs in Serbia for the same period as in RS, were taken from the annual reports of the Agency for drugs and Medical Devices of the Republic of Serbia [6]. The given data represent the overall out-patient and in-patient use of drugs in 2013. Data on the use of these drugs in Norway were taken from the annual report that is regularly issued in electronic format, and also represent total sale, referring to both out-patient and in-patient drug consumption in 2013 [7]. For Hungary, data on the use of antidiabetic drugs were obtained from the National Medicine Agency, and represent sales from wholesalers, referring to both out-patient and in-patient use of drugs in 2013. The utilization of antidiabetic drugs was analyzed by using the ATC/ Defined Daily Dose (DDD) methodology valid in 2013 [8]. The theoretical exposure of patients with DM to antidiabetic drugs was expressed in percentage.

\section{RESULTS}

Prevalence of DM in the adult population estimated by the IDF for 2013 in Norway and Hungary was $4.7 \%$ and $6 \%$, while in Serbia and Bosnia and Herzegovina it was more than 9\%. Real prevalence in the sample of adult population in the eastern part of the RS was $6.65 \%$ (Table 1).

The total number of patients with 

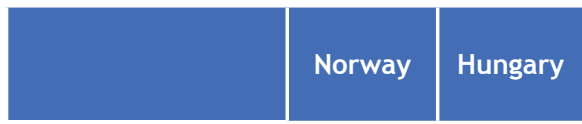

$4.7^{*}$

$6.03^{*}$

DM prevalence (\%)

$6.03 *$

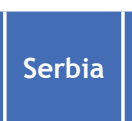

9.92 type $1 \mathrm{DM}$ in the three observed municipalities was $757(1.68 \%)$, while the number of patients with type $2 \mathrm{DM}$ was 2233 (4.96\%). (Table 2).

More than $25 \%$ of all patients with diabetes mellitus had diagnosis of DM type 1 (Figure 1).

The total consumption of antidiabetic drugs was higher in Serbia and Hungary compared to the RS and Norway (Table 3).

\section{Bosnia and Herzegovina}

$9.7^{*}$
Eastern part of the Republic of Srpska, real prevalence in the three municipalities
Table 1. Estimated prevalence of diabetes mellitus in the adult population of Norway, Hungary, Serbia and Bosnia and Herzegovina and real prevalence of DM in the eastern part of the Republic of Srpska in 2013 year

[9-12]. Moreover, our results show that the real prevalence is substantially lower prevalence than the one from the IDF Diabetes Atavailable data on prevalence among adults for the both administrative entities of $\mathrm{BiH}$ ).

Lower real prevalence of DM recorded in our study in the eastern $\mathrm{BiH}$ than it is estimated by the 2013 IDF Diabetes Atlas im-

* the estimated prevalence of diabetes in ad ult population by the IDF for 2013 is available only for the Bosnia and Herzegovina, there is no separate data for the entities - Republic of Srpska and Federation of Bosnia and Herzegovina las $(9.7 \%)$ for 2013 (which is currently the only
Total number of population the three observed municipalities in the RS ( $n$ )

Total number of adults in the the three observed municipalities in the RS (n)

Prevalent cases of DM type 1 (n)

Prevalence of DM type 1 (\%)

Prevalent cases of DM type 2 (n)

Prevalence of DM type 2 (\%)

Total prevalence of DM (\%)
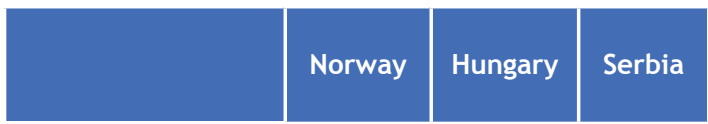

Bosnia and Herzegovina
Eastern part of the Republic

of Srpska, real prevalence in the three municipalities

\section{Diabetes prevalence (\%) \\ Utilization of OAHDs (DDDs/TID)}

Utilization of insulins (DDDs/TID)

\begin{abstract}
$4.7 \% *$
\end{abstract}
$6.03 \%$ *

9.92\%*

$9.7 \% *$

$6.65 \% * *$

29.69

53.50

66.38

NA

$36.36^{* * *}$

Total utilization of antidiabetic drugs (insulins and OAHDs) (DDDs/TID)

\section{Theoretical} exposure of each patient with diabetes to 19.12

22.79

13.58

NA

$15.67^{* * *}$ antidiabetic drugs (\%)

\section{DISCUSSION}

According to the literature data, our study was the first to examine the real prevalence of DM in one region in the $\mathrm{BiH}$, which is noteworthy considering the fact that estimates on prevalence of DM are limited by a paucity of data, particularly for Southeastern Europe. The recorded prevalence $(6.65 \%)$ is similar or lower than those from other Southeastern countries
Table 2. Prevalent cases and prevalence of diabetes mellitus in three observed municipalities of the eastern part of the Republic of Srpska (RS)

Table 3. Overview of the estimated prevalence of diabetes in the adult population, the utilization of antidiabetic drugs (insulins and OAHDs) as well as the theoretical exposure of patients with diabetes to antidiabetic drugs in Norway, Hungary, Serbia, Bosnia and Herzegovina and in the three observed municipalities of the Eastern part of the Republic of Srpska in 2013 (DDDs/TID)

* the estimated prevalence of diabetes in adult population by the IDF for 2013; it is available only for the Bosnia and Herzegovina, there is no separate data for the entities - Republic of Srpska and Federation of Bosnia and Herzegovina

** real prevalence of DM real in the three municipalities in the Republic of Srpska in 2013 year

poses some questions. Is the diagnosis of DM inadequate in the RS? As a check, the proportion of DM type 1 and type 2 can be taken. Although the relative proportions of type 1 and type 2 diabetes have not been reported in sufficient detail in low- and middle income countries, studies in high-income countries have estimated that aproximately $87 \%$ to $91 \%$ of all patients with diabetes to have type 2 [13-17]. In case of our study conducted in in the east-
*** the consumption in three observed municipalities of the Republic of Srpska in 2013 year 
Figure 1. The proportion of diabetes mellitus type 1 and 2 in three observed municipalities of the eastern part of the Republic of Srpska, Bosnia and Herzegovina

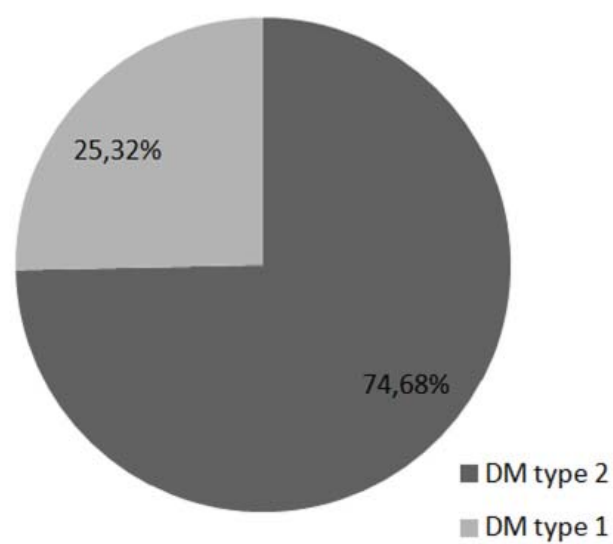

ern part of RS , the average proportion of DM type 2 among the patients with diabetes was only $74.68 \%$ while the proportion of type 1 was $25.32 \%$. The most cases of type 1 diabetes are detected soon after symptoms develop due to the acute onset of symptoms and impossibility to leave without supstitution. The number of patients with type $1 \mathrm{DM}$ was 757 in our study and if we take into account that the proportion of type 1 to type 2 in general population is $1: 9$, then the number of patients with type 2 would be 6813 whereas the total number of patients with DM would be 7570 in the RS. It means that only $39 \%$ of patients (2990 out of 7570 ) with DM are diagnosed in the RS, while approximetly $61 \%$ (4580 out of 7570 ) of them are still undiagnosed, mainly those with type 2 DM.

Differences in methodology, diagnostic and temporal variations make it difficult to compare our results with data from other studies. However, similar high prevalence of undiagnosed DM type 2 was recorded in the other observed countries in our study. For instance, lower prevalence of DM was assessed in Hungary (according to a registration for diabetic medicine users) and Serbia (according to the registrated patients with diabetes) than it was estimated by the 2003 IDF Diabetes Atlas (5.23\% vs. 9.7\% for 2003 and $1.9 \%$ vs. $5,6 \%$, respectively), which also indicate that many patients with DM in Hungary as well as in Serbia are undiagnosed [18,11]. There is no data on the total prevalence of undiagnosed DM in Serbia, but in case of Hungary the results of the latest screening based on FINDRISC questionnaire (including oral glucose tolerance test) showed that the prevalence of manifest, previously undiagnosed DM was even higher, $7.6 \%$ [19]. In Norway, according to a registration for diabetic medicine users, the recorded prevalence of DM (3.2\%) was more comparable to the one estimated by the 2013 IDF Diabetes Atlas (5.7\%) than in case of Central or Southeastern countries in Europe. However, population-based study based on fasting serum glucose analysis reported that the the proportion of undiagnosed diabetes was higher than anticipated, and constituted $39 \%$ of all those patients categorized as diabetics [20].

Although type 2 diabetes can remain undiagnosed for many years, the chronic hyperglycemia of diabetes is associated with long-term damage, dysfunction, and failure of various organs, leading to blindness, limb amputation, kidney failure, vascular and heart disease. Sevenfold increase in mortality was revealed in Type 2 diabetic patients with hypertension compared to non-diabetic, normotensive patients. Similarly, individuals with undiagnosed type 2 diabetes are also at significantly higher risk for coronary heart disease, stroke, and peripheral vascular disease than the nondiabetic population [21]. Furthermore, the costs related to undiagnosed diabetes are considerable.

For all the above-mentioned facts, the question is: What can be done in the $\mathrm{BiH}$ ? In former Yugoslavia, $\mathrm{BiH}$ and Serbia being a part of it, community screening programs to identify individuals with hyperglicaemia were performed on a regular basis. Unfortunately, after Yugoslavia disintegrated, these activities were not continued in former Yugoslav countries.

The World Health Organisation has called for action on both the population as well as high risk group patients in 2003 [22]. Almost 13 years after that, in many European countries there are no comprehensive series of actions aimed to detect individuals with DM and to reduce the already-large health and economic impacts of consequences of improperly diabetes, especially in Southeastern Europe [9-12]. While undiagnosed diabetes is a substantial problem, population-wide screening for diabetes is not appropriate. For instance, in Hungary, besides the aforementioned risk stratified diabetes screening, only a few other similar studies were conducted according to the available literature $[23,24]$. Similarly, in Norway, approximately 150000 persons have tested their risk of diabetes by the self score test based on the Finnish FindRisk test [25]. 
The availability of data from the reimbursement schemes in our study provided a unique opportunity to examine the medical treatment of DM in the population of the eastern $\mathrm{BiH}$, RS. Although antidiabetic drugs (A10) were among top 5 ATC groups according to the value-based turnover of dispensed medicines in five year time (2009-2013) in the RS (with the the highest, 10.6 million euros total increase in value prescriptions dispensed), the obtained percentage of theoretical exposure of each patient to at least $1 \mathrm{DDD}$ of at least one antidiabetic drug in our study was only $78,24 \%$ (calculated from the total utilization of antidiabetic drugs and from the estimated prevalence) (Table 4). The exposure rate recorded in the neighboring Serbia was similar (80.6\%), whereas Norway and especially Hungary had exceptionally good exposure rates $(103,8$ and $126.5 \%)$. The lower number of DDD/TIDs than the percentage of patients in the Republic of Srpska shows that even the known patients with DM type 2 are not sufficiently treated. Furthermore, the total consumption of antidiabetic drugs in the three observed municipality in our study (52.03 DDD/TIDs) was higher than the one published by the Institute of Public Health Republic of Srpska for the same year (33.016 DDD/TIDs) [26]. However, it should be emphasized that the consumption of antidiabetic drugs in the three municipalities Foca, Gacko and Trebinje (39.66 DDD/TIDs, 42.78 DDD/TIDs, 62.68 DDD/TIDs, respectively) correlated to the diabetes prevalence $(4.12 \%$, $6.04 \%, 8.44 \%$, respectively). This supports the view that geografic differences in the consumption of antidiabetic drugs may indicate the differences in the prevalence of diabetes. Although, drug utilization data can not substitute for prevalence studies, they may help to find areas where prevalence comparisons should be performed [27].

There are some limitations of the study. Consumption data included antidiabetic drugs issued under prescription (reimbursement data), but not drugs bought without prescription or drugs used by inpatient departments in the RS. Furthermore, our study does not provide information about the treatment of each patient, patients compliance with medication or the application of combination therapy of each drug. Although it was designed as a representative survey, no oral glucose tolerance test was performed and, accordingly, it can be assumed that some pa- tients with diabetes could not be identified and patients with impaired glucose tolerance could not be detected.

\section{CONCLUSION}

Overall, the present study emphasises the high percentage of patients with undiagnosed DM in the eastern part of the Republic of Srpska, $\mathrm{BiH}$. Even the registered patients with DM are undertreated, indicating the necessity for complex actions to improve their therapy. In order to take more effective actions against this important silent main killer of civilization, our data call attention to the urgent need of public health prevention programs addressed to persons with known and yet unknown DM in the $\mathrm{BiH}$.

\section{ACKNOWLEDGEMENTS}

This study was funded by the Ministry of Science and Technological Development, Republic of Serbia (project No. 41012).

\section{REFERENCES}

1. International Diabetes Federation. IDF DIABETES ATLAS. 6th ed. 2013.

2. Murray, C. J. L., Lopez A.D., Vos t. et al. and GBD 2013 DALYs and HALE Collaborators. Global, regional, and national disability-adjusted life years (DALYs) for 306 diseases and injuries and healthy life expectancy (HALE) for 188 countries, 19902013: quantifying the epidemiological transition. Lancet 2015; 386 (10009): 2145-91.

3. Murray, C. J. L., Lopez A.D., Vos t. et al. and GBD 2013 Mortality and Causes of Death Collaborators. Global, regional, and national age-sex specific all-cause and cause-specific mortality for 240 causes of death, 1990-2013: a systematic analysis for the Global Burden of Disease Study 2013. Lancet 2015; 385(9963):117-71.

4. Institute for Health Meatrics and Evaluation, document available on http://www.healthdata. org/bosnia-and-herzegovina

5. Agency for Statistics of Bosnia and Herzegovina. Census of Population, Households and Dwellings in Bosnia and Herzegovina, 2013 final results. Sarajevo: Agency for Statistics of Bosnia and Herzegovina; 2016. Available at: http://www.popis2013.ba/popis2013/doc/Popis2013prvolzdanje.pdf [Accessed $28 \mathrm{Nov}, 2016$ ]

6. Radonjić V, Dukić Lj. Trade and consumption of the medicinal products-Annual reports 2013. Belgrade: Medicines and Medical Devices Agency of Serbia;2012. (hard copy in Serbian language) 
7. Sakshaug $S$ (ed). Drug Consumption in Norway 2009-2013(Legemiddelforbruket i Norge 2009-2013). Oslo: Norwegian Institute of Public Health(legemiddelstatistikk); 2014:1. Available at: http://www. fhi.no/dokumenter/6f9b71d72a.pdf [Accessed 05 August 2013].

8. World Health Organization Collaborating Centre for Drug Statistics Metodology. About the ATC/DDD system. Available from: http:// www.whocc.no/ atcddd/. [Accessed 28 Sep, 2016].

9. Mota M, Popa SG, Mota E. et al. Prevalence of diabetes mellitus and prediabetes in the adult Romanian population: PREDATORR study. J Diabetes. 2016 May;8(3):336-44.

10. Gikas A, Sotiropoulos A, Panagiotakos D, Peppas T, Skliros E, Pappas S. Prevalence, and associated risk factors, of self-reported diabetes mellitus in a sample of adult urban population in Greece: MEDICAL Exit Poll Research in Salamis (MEDICAL EXPRESS 2002). BMC Public Health 2004 14;4:2.

11. Mladenović V, Pantović V, Djukić A. et al. Epidemiological characteristics of diabetic patients in Kragujevac. Medical Journal of Serbian Medical Society Sectio Kragujevac 2008; 42(2):07-12.

12. Metelko Z, Pavlić-Renar I, Poljicanin T, Szirovitza L, Turek S. Prevalence of diabetes mellitus in Croatia. Diabetes Res Clin Pract. 2008 Aug;81(2):263-7.

13. Matelko Z, Granic M i Skrabalo Z. Secerna bolest. U: Interna Medicina. Vrhovac B. Naprijed, Zagreb, 2003. 1264-84.

14. Mandolfino F, Frascio M, Perotti S, Lazzara F, Imperatore $M$, Bruno $S$. Diabetes Mellitus and upper gut motility. J Biol Res. 2013;86(1):25-8.

15. Stankovic $Z$, Jašovic-Gašic $M$, Lecic-Toševski D. Psychological problems in patients with type 2 diabetes - Clinical considerations. Vojnosanit Pregl 2013; 70(12): 1138-44.

16. de Pablos Velasco P, Franch J, Banegas Banegas JR, Fernández Anaya S, Sicras Mainar A, Díaz Cerezo S. Cross-sectional epidemiological study of clinical profiles and glycemic control in diabetic patients in primary care in Spain (the EPIDIAP study). Endocrinol Nutr. 2009;56(6):330.

17. Fabian W, Majkowska L, Stefański A, Moleda P. Prevalence of diabetes, antidiabetic treatment and chronic diabetic complications reported by general practitioners. Przegl Lek. 2005;62(4):201-5.

18. Doró $P$, Benko R, Kosik E, Matuz M, Tóth K , Soós $G$ Utilization of oral antihyperglycemic drugs over a 7-year period (1998-2004) in a Hungarian population and adherence to drug therapy. Eur $\mathrm{J}$ Clin Pharmacol. 2005; 61: 893-7.

19. Winkler G, Hídvégi T, Vándorfi G, Balogh $\mathrm{S}$, Jermendy $\mathrm{G}$. Prevalence of undiagnosed abnormal glucose tolerance in adult patients cared for by general practitioners in Hungary. Results of a risk-stratified screening based on FINDRISC questionnaire. Med Sci
Monit. 2013 Jan 24;19:67-72.

20. Karen Jenum A, Lorentzen C, Anderssen SA, Birkeland KI, Holme I, Lund-Larsen PG, Ommundsen Y, Raastad T, Thelle DS, Bahr R. Promoting physical activity in a multi-ethnic district - methods and baseline results of a pseudo-experimental intervention study. Eur J Cardiovasc Prev Rehabil. 2003;10(5):387-96.

21. The hypertension in Diabetes Study Group. Hypertension in Diabetes Study (HDS): II. Increased risk of cardiovascular complications in hypertensive type 2 diabetic patients. J Hypertens 1993;11(3):319-25.

22. Report of a Joint WHO/FAO Expert Consultation. Diet, nutrition and the prevention of chronic diseases. 916. Geneva: World Health Organization. WHO technical Report Series; 2003.

23. Vamos EP, Kopp MS, Keszei A, Novak M, Mucsi I. Prevalence of diabetes in a large, nationally representative population sample in Hungary. Diabetes Res Clin Pract. 2008;81(3):e5-8.

24. Jermendy G, Nádas J, Szigethy E, Széles G, Nagy A, Hídvégi T, Paragh G, Adány R. Prevalence rate of diabetes mellitus and impaired fasting glycemia in Hungary: cross-sectional study on nationally representative sample of people aged 20-69 years. Croat Med J. 2010;51(2):151-6.

25. Berg TJ. National diabetes strategy and diabetes epidemiology in Norway. Norsk Epidemiologi 2013;23(1):3-4.

26. Institut za javno zdravstvo Republike Srpske. Izvjestaj o potrosnji i prometu gotovih lijekova u Republici Srpskoj u 2013. godini. Banja Luka: Institut za javno zdravtsvo; 2014.

27. Olsson J, Tollin C, Nilsson S, Melander A. Intercommunity variations in antidiabetic drug utilization and in prevalence of diabetes mellitus. Pharmacoepidemiology and Drug Safety 1994; 3:(4):185-246. 


\title{
Prevalencija dijabetes melitusa i upotreba antidijabetičnih lekova u istočnoj Bosni i Hercegovini: pilot studija
}

\author{
Jelena D. Popržen ${ }^{1}$, Zdenko S. Tomić ${ }^{2}$, Ana D. Tomas², Milica M. Paut Kusturica², \\ Ana J. Sabo ${ }^{2}$, Olga J. Horvat ${ }^{2}$ \\ ${ }^{1}$ Zdravstvena ustanova Moja apoteka, Foča, Republika Srpska, Bosna i Hercegovina \\ ${ }^{2}$ Katedra za farmakologiju i toksikologiju, Medicinski fakultet, Univerzitet u Novom Sadu, Novi Sad, Srbija
}

\section{KRATAK SADRŽAJ}

Ne postoje kompletirani nacionalni podaci o prevalenciji dijabetes melitusa (DM) u Bosni i Hercegovini $(\mathrm{BiH})$, a jedini dostupni podaci nastali su ekstrapolacijom podataka iz susednih zemalja. Ovo istraživanje studija imalo je za cilj da utvrdi prevalencuiju DM, kao i upotrebu antidijabetičkih lekova $(A D)$ i stopu izloženosti pacijenata sa $\mathrm{DM} A \mathrm{D}$ u istočnom regionu Republike Srpske (RS), BiH. Podaci o upotrebi upoređeni sa podacima iz Srbije, Mađarske i Norveške. Podaci o broju svih odraslih pacijenata sa DM tipovima 1 i 2 u tri opštine $u$ istočnom regionu RS dobijeni su iz medicinske dokumentacije. Upotreba AD u RS, Srbiji, Mađarskoj i Norveškoj za 2013. godinu analizirana je primenom ATC/DDD metodologije. Izloženost pacijenata sa DM AD izražena je u procentima. Zabeležena prevalencija DM u tri posmatrane opštine iznosila je $6,65 \%$, sa visokim udelom tipa 1 u poređenju sa tipom 2 DM (25,32\% do 74,68\%). Ukupna potrošnja $A D$ zabeležena u našem ispitivanju studiji bila je slična upotrebi u Norveškoj, ali niža nego u Srbiji i Mađarskoj. Procenat teorijske izloženosti svakog pacijenta AD iznosio je samo $78,24 \%$, slično izloženosti u Srbiji $(80,6 \%)$, dok su Norveška a posebno Mađarska imali izuzetno visoku izloženost $(103,8$ i $126,5 \%)$. Visoki procenat pacijenata sa tip 1 DM zabeleženih u našoj studiji ukazuje na nedovoljno otkrivanje DM, posebno tipa 2, dok je niska stopa izloženosti pacijenata sa DM AD ukazuje na to da su čak i registrovani pacijenti sa DM nedovoljno lečeni. Postoji hitna potreba za intervencijama u prevenciji i lečenju DM u BiH.

Ključne reči: dijabetes melitus; antidijabetični lekovi; Bosna i Hercegovina; ATC-DDD 